\title{
Synthesis and Characterization of Magnesium Borate via Sol-Gel Method and Electrospinning Method
}

\author{
Esra Nur Doğana1, Fatih Demir ${ }^{2}$ \\ 1Eti Maden İşletmeleri, Ankara, Turkey \\ ${ }^{2}$ Department of Chemical Engineering, Ataturk University Engineering, Ezurum, Turkiye
}

\begin{abstract}
How to cite this paper: Esra Nur Dogana | Fatih Demir "Synthesis and Characterization of Magnesium Borate via Sol-Gel Method and Electrospinning Method" Published in International Journal of Trend in Scientific Research and Development (ijtsrd), ISSN: 24566470, Volume-3 | Issue-3, April 2019, pp.129-134, URL: http://www.ijtsrd.co $\mathrm{m} /$ papers/ijtsrd216 62.pdf

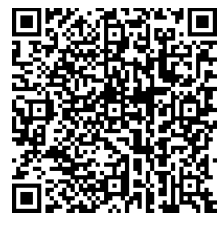
IITSRD21662
\end{abstract}

Copyright (C) 2019 by author(s) and International Journal of Trend in Scientific Research and Development Journal. This is an Open Access article distributed under the terms of the Creative Commons

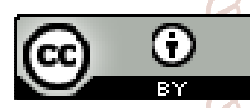
Attribution License (CC BY 4.0) (http://creativecommons.org/licenses/ by $/ 4.0$ )

\section{INTRODUCTION}

Nanotechnology science deals with the design and control of both nanosized shapes and dimensions, and the structure, system, production, characterization and its applications. The one-dimensional nanoscale materials such as nanofibers, nanorods and nanowires have gained considerable attention in recent years owing to the technological applications [1-5]. Nanofiber materials are widely used for nanotechnology applications because of their properties which are different from macro size due to their properties such as conductivity, reactivity and strength for nanotechnology applications. Nanosize materials display superior chemical, mechanical, optical, electronicand magnetic properties for a wide range of applications because of their small dimensions and high surface areas ${ }^{[7-9]}$.

Magnesium borates exist the minerals of economic importance like hydroboracite $\left(\mathrm{CaMgB}_{6} \mathrm{On}-6 \mathrm{H}_{2} \mathrm{O}\right)$ and szaibelyite $\left(\mathrm{Mg}_{2} \mathrm{~B}_{2} \mathrm{O}_{5}-\mathrm{H}_{2} \mathrm{O}\right)$ structure in nature. They are synthesized in the forms of $\mathrm{MgO}_{2} \mathrm{~B}_{2} \mathrm{O}_{3} \cdot \mathrm{nH}_{2} \mathrm{O}, 2 \mathrm{MgO}-$ $3 \mathrm{~B}_{2} \mathrm{O}_{3} \cdot \mathrm{nH}_{2} \mathrm{O}$ etc. [10-14]. Magnesium borates are important a ceramic material that shows excellent mechanical and thermal properties such as the required catalysts for the conversion of hydrocarbons. Various methods for the preparation of magnesium borates are used the thermal syntheses, microwave heating or chemical vapor deposition methods, including solid state reactions, co-precipitation, mechano-chemical complexation and electrospinning method [15-18].

In the recent years, Electrospinning is the easiest technique utilized in production of functional nanofibers such as alumina, silica, magnesium borates etc. This technique has been used to be simple to obtain metal oxide composites possessing small-diameter particles high specific surface area, which are useful in a variety of applications ${ }^{[19-20]}$. The important advantages of this technique are the ability to control with accuracy the fiber, a high aspect ratio of the products, not expensive at the laboratory scale. But, disadvantages of this method are that the method requires high voltage usually in the $10-40 \mathrm{kV}$ range, only a few polymers are currently applied for preparation of organic nanofibers and the range of application of electrospun inorganic nanofibers has been limited due to their fragility after calcination and it is the low yield in the low flow rates are indeed required to achieve nano-scale fiber diameters [21].

In a recent work, Storti et al., the electrospinning technique for the synthesis of magnesium borate fibers investigated. They obtained the presence of fibers with diameters in the $100-300 \mathrm{~nm}$ range after heat treatment at $800{ }^{\circ} \mathrm{C}$ and 1000 ${ }^{\circ} \mathrm{C}$ [21]. In another study, a new one-dimensional 
nanostructure, $\mathrm{Mg}_{3} \mathrm{~B}_{2} \mathrm{O}_{6}$ nanobelts were synthesized by thermal treating of the mixed powders of boron and magnesium oxide in the presence of $\mathrm{H}_{2} \mathrm{O}$ vapor. Magnesium borate nanobelts were prepared by heating mixed powders of boron and $\mathrm{MgO}$ under flowing $\mathrm{Ar} / \mathrm{H}_{2} \mathrm{O}$ gases at $1100{ }^{\circ} \mathrm{C}$, and typical widths of the nanobelts were obtained in the range of 100-300 $\mathrm{nm}$ [22]. Sevim et al. Nanofibers of PVA /nickel nitrate/silica/alümina izopropoxide/boric acid composite prepared by using sol-gel processing and electrospinning technique. As a result, By high temperature calcinations of the above precursor fibers, nanofibers of $\mathrm{NiO} / \mathrm{Al}_{2} \mathrm{O}_{3} / \mathrm{B}_{2} \mathrm{O}_{3} / \mathrm{SiO}_{2}$ composite with diameters about 500 $\mathrm{nm}$ were successfully obtained [23].

In this paper, we present the production of pure magnesium borate nanofibers by the calcination of inorganic composite fibers obtained through electrospinning by sol-gel method. We report a production nanofibers and characterization of magnesium borate nanofibers. This study may be useful to investigate the possibilities of commercial application of the magnesium borate nanofibers in the coming years.

\section{EXPERIMENTAL}

The boron source of boric acid $\left(\mathrm{H}_{3} \mathrm{BO}_{3}\right)$ is retrieved from Etibank Emet Boron and Acid Factory in Turkey. The electrospinning sol-gel solutions consisted of $\mathrm{Mg}\left(\mathrm{NO}_{3}\right)_{2}$ (Merck,>99\%), hydrochloric acid (Sigma-Aldrich, 37\%), polyvinyl alcohol (PVA Mw $=240.000 \mathrm{~g} / \mathrm{mol}$, SigmaAldrich), ethanol (Sigma-Aldrich, $>99 \%$ ) and distilled water. The aqueous solution of PVA was firstly prepared by dissolving $10 \mathrm{~g}$ PVA powder in $100 \mathrm{ml}$ distilled water stirring for $2 \mathrm{~h}$ at $80{ }^{\circ} \mathrm{C}$. Then it was cooled to room temperature by stirring continued for $12 \mathrm{~h}$. The gel solution was prepared by mixing ethanol, concentrated $\mathrm{HCl}$ and distilled water all together. The mixed solution was kept with magnetic stirring for $2 \mathrm{~h}$ in a room temperature. In another bowl, PVA and boric acid were mixed with magnesium nitrate. Then the other solutions were added into the prepared PVA solution under stirring at a slow speed in a particular order. The $\mathrm{pH}$ of the medium must be below 2 because of it is prevented peptization during the formation of the sol-gel. Then the gel composite was filled in a plastic syringe $(10 \mathrm{ml})$ and placed into syringe pump. A copper wire connected to a high-voltage device was attached to the plastic syringe by adjusting the angle between the fixing bar and the capillary tip. A voltage $15 \mathrm{kV}$ and the feed $0.3 \mathrm{ml} / \mathrm{h}$ rate was applied to the gel. The fibers were accumulated on the aluminum foil. Measured fiber diameters were obtained on solution \%10 PVA, distance $15 \mathrm{~cm}$ and voltage $15 \mathrm{kV}$ in ideal working conditions. The fibers occurred were firstly dried at $110{ }^{\circ} \mathrm{C}$ for $2 \mathrm{~h}$ and then calcined in air at $800{ }^{\circ} \mathrm{C}$ and $1200{ }^{\circ} \mathrm{C}$, standing at a heating rate of $2{ }^{\circ} \mathrm{C} / \mathrm{min}$ for $2 \mathrm{~h}$, respectively. The magnesium borate nanofibers were obtained.
DTA and TG were operated on a NETZSCH STA 449F3 thermo-processing in air at a temperature range of 0-1200 ${ }^{\circ} \mathrm{C}$ and thermal experiments were treated with a certain sample weight. The sample was established a platinum crucible and its dehydration was recorded at the $10^{\circ} \mathrm{C} \mathrm{min}-1$ of constant heating rate under nitrogen atmosphere with 20 min of a purge time and $25 \mathrm{ml} / \mathrm{min}$ of a flow rate.

The absorbance spectra of deposited nanofibers of Magnesium borate composite on Au Plates were measured using a different angle reflection equipment in conjunction with a Perkin-Elmer Spectrum One FTIR spectroscopy in the range of $4000-400 \mathrm{~cm}^{-1}$ at room temperature. All the measurements were obtained with a resolution of $2 \mathrm{~cm}^{-1}$ and an average of 100 scans. SEM (Philips XL30 SFEG) was investigated the morphologies of the samples. SEM images were recorded using a Leco 1430 V.P. SEM instrument with 12-24 kV accelerating voltage and 130-150 pA beam current.

XRD (The thermobalance measured mass to $0.001 \mathrm{mg}$, with an accuracy of $\pm 1 \%$.) experiments for nanofilms on nanofibers of Magnesium borate composite were measured with a Rigaku Advance Powder X-ray Diffractometer device using $\mathrm{Cu}$ K $\alpha$ radiation $(\lambda=1.5405 \AA)$, operating at $30 \mathrm{~mA}$ and $30 \mathrm{kV}$ about a $2 \mathrm{~h}$ range of $20-60^{\circ}$. The XRD phases were identified with the help of the Joint Committee on Powder Diffraction Standards-International Center for Diffraction Data (JCPDS-ICDD).

\section{RESULTS AND DISCUSSION}

3.1. Differential Thermal and Thermogravimetric Analysis (DTA/TG):

The TG and DTA results are shown in Fig. 1. As seen from the DTA curve two endothermic peaks, related with the loss of absorbed water, dehydration on the side chain of polymer and degradation of remaining alkyl groups, are around 165.4 and $283.3{ }^{\circ} \mathrm{C}$. In addition to those, the organic groups and PVA were utterly removed at 400-500 ${ }^{\circ} \mathrm{C}$. As seen TG curve, the loss of sample weight was obtained about $80 \%$. Above the temperature of $600{ }^{\circ} \mathrm{C}$ related to the formation of pure inorganic oxide in crystalline form, there is not seen any loss of weight. Equations (1), (2) and (3) describe the room temperature and thermal process, respectively;

$$
\begin{aligned}
& 7 \mathrm{Mg}\left(\mathrm{NO}_{3}\right)_{2}+4 \mathrm{H}_{3} \mathrm{BO}_{3}+14 \mathrm{NaOH} \rightarrow \mathrm{Mg}_{7} \mathrm{~B}_{4} \mathrm{O}_{13} \cdot 7 \mathrm{H}_{2} \mathrm{O}(\mathrm{s})+ \\
& 14 \mathrm{NaNO}_{3}+6 \mathrm{H}_{2} \mathrm{O} \\
& \mathrm{Mg}_{7} \mathrm{~B}_{4} \mathrm{O}_{13} \cdot 7 \mathrm{H}_{2} \mathrm{O}(\mathrm{s})+3 \mathrm{H}_{3} \mathrm{BO}_{3} \rightarrow 7 \mathrm{MgBO}_{2}(\mathrm{OH})(\mathrm{s})+8 \mathrm{H}_{2} \mathrm{O} \text { (2) } \\
& 2 \mathrm{MgBO}_{2}(\mathrm{OH})(\mathrm{s}) \rightarrow \mathrm{Mg}_{2} \mathrm{~B}_{2} \mathrm{O}_{5}(\mathrm{~s})+\mathrm{H}_{2} \mathrm{O}
\end{aligned}
$$




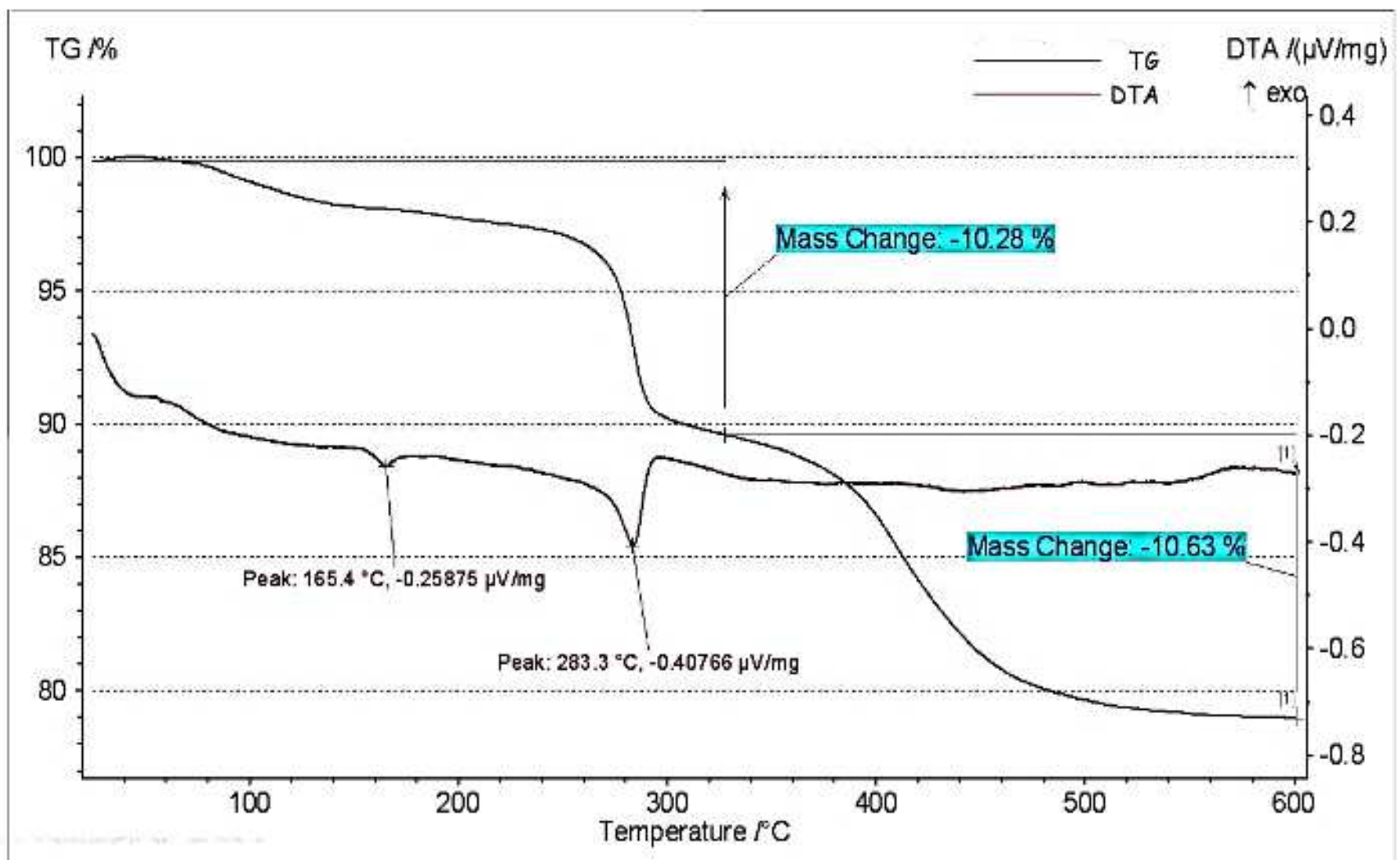

Fig.1. TG-DTA thermogravimeter for the composite fibers of the $\mathrm{Mg}_{2} \mathrm{~B}_{2} \mathrm{O}_{5} / \mathrm{PVA}$ in nitrogen atmosphere

\subsection{Fourier Transform Infrared (FT-IR):}

Fig. 2-3 shows the FT-IR spectra the $\mathrm{Mg}_{2} \mathrm{~B}_{2} \mathrm{O}_{5}$ /PVA fibers at room temperature, and for those sintered at temperatures of $800^{\circ} \mathrm{C}$ and $1200^{\circ} \mathrm{C}$, respectively. In Figures, the $\mathrm{Mg}_{2} \mathrm{~B}_{2} \mathrm{O}_{5} / \mathrm{PVA}$ fibers show a broad peak at $3272 \mathrm{~cm}^{-1}$ corresponding to $\mathrm{H}-\mathrm{OH}$ stretch; and the characteristic absorption peaks at about 2916, 2624,2021, 1655, 1325 and 1086 corresponding to vibration bands of $\mathrm{C}-\mathrm{C}, \mathrm{C}-\mathrm{H}, \mathrm{O}-\mathrm{H}, \mathrm{C}-\mathrm{O}$, respectively. The $\mathrm{BO}_{3}$ in $826 \mathrm{~cm}^{-1}$ and $1412 \mathrm{~cm}^{-1}$ peaks, $\mathrm{BO}_{4}$ in $914 \mathrm{~cm}^{-1}$ and $1086 \mathrm{~cm}^{-1}$ peaks and BOH in $1325 \mathrm{~cm}^{-1}$ peak is indicated the structure of bonds in Fig.2-3. In sintering, between $800{ }^{\circ} \mathrm{C}$ and $1200{ }^{\circ} \mathrm{C}$, all peaks forming from water and organic structures almost disappeared. In addition, at these temperatures clear new peak groups, which may be associated to the formation of inorganic phase crystalline, appears at $800-1650 \mathrm{~cm}^{-1}$. Thus, it may be received that these peaks over and over each other.

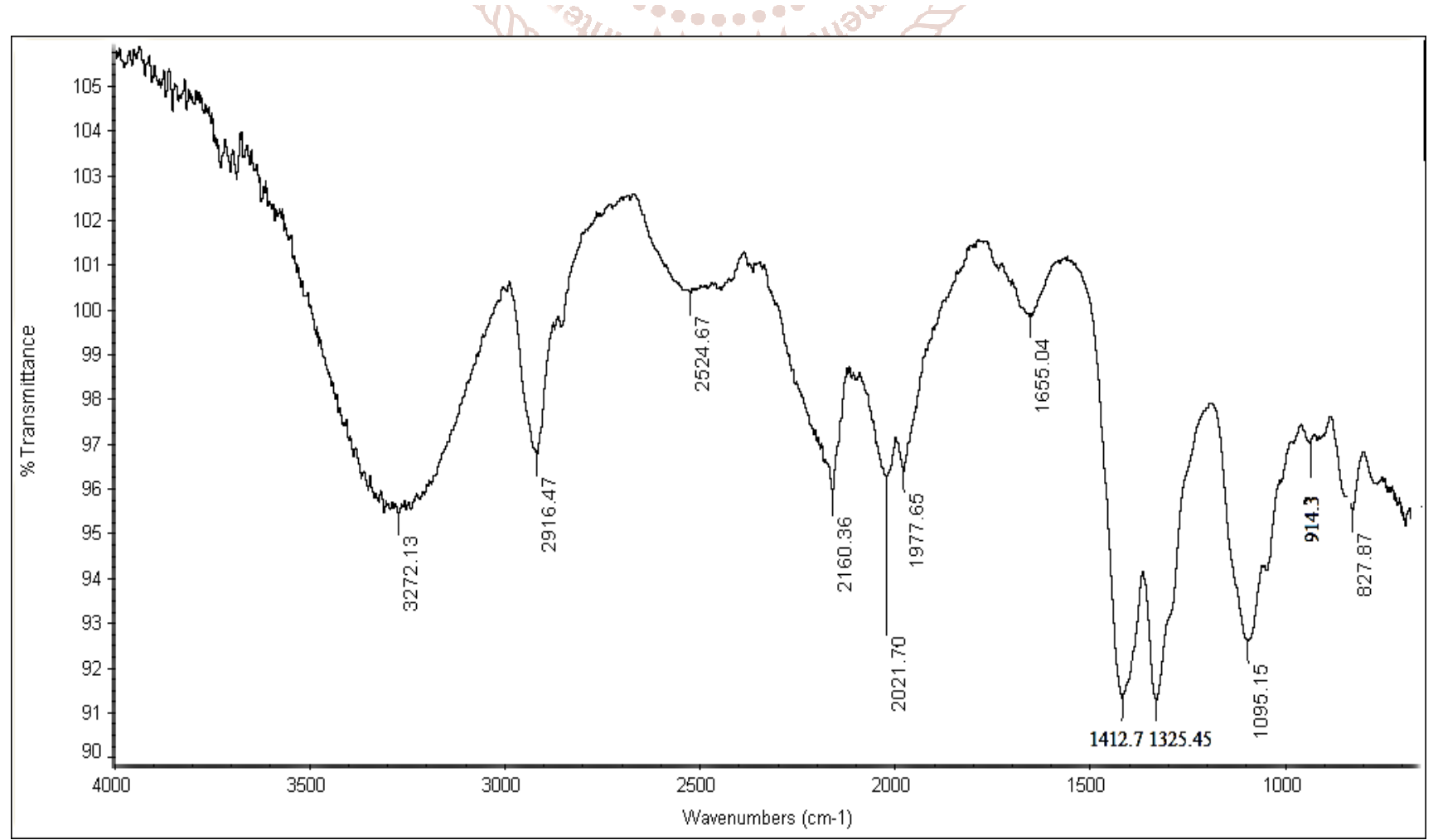

Fig.2. FT-IR spectrum analysis for the composite fibers of the $\mathrm{Mg}_{2} \mathrm{~B}_{2} \mathrm{O}_{5} / \mathrm{PVA}$ at $800{ }^{\circ} \mathrm{C}$ 


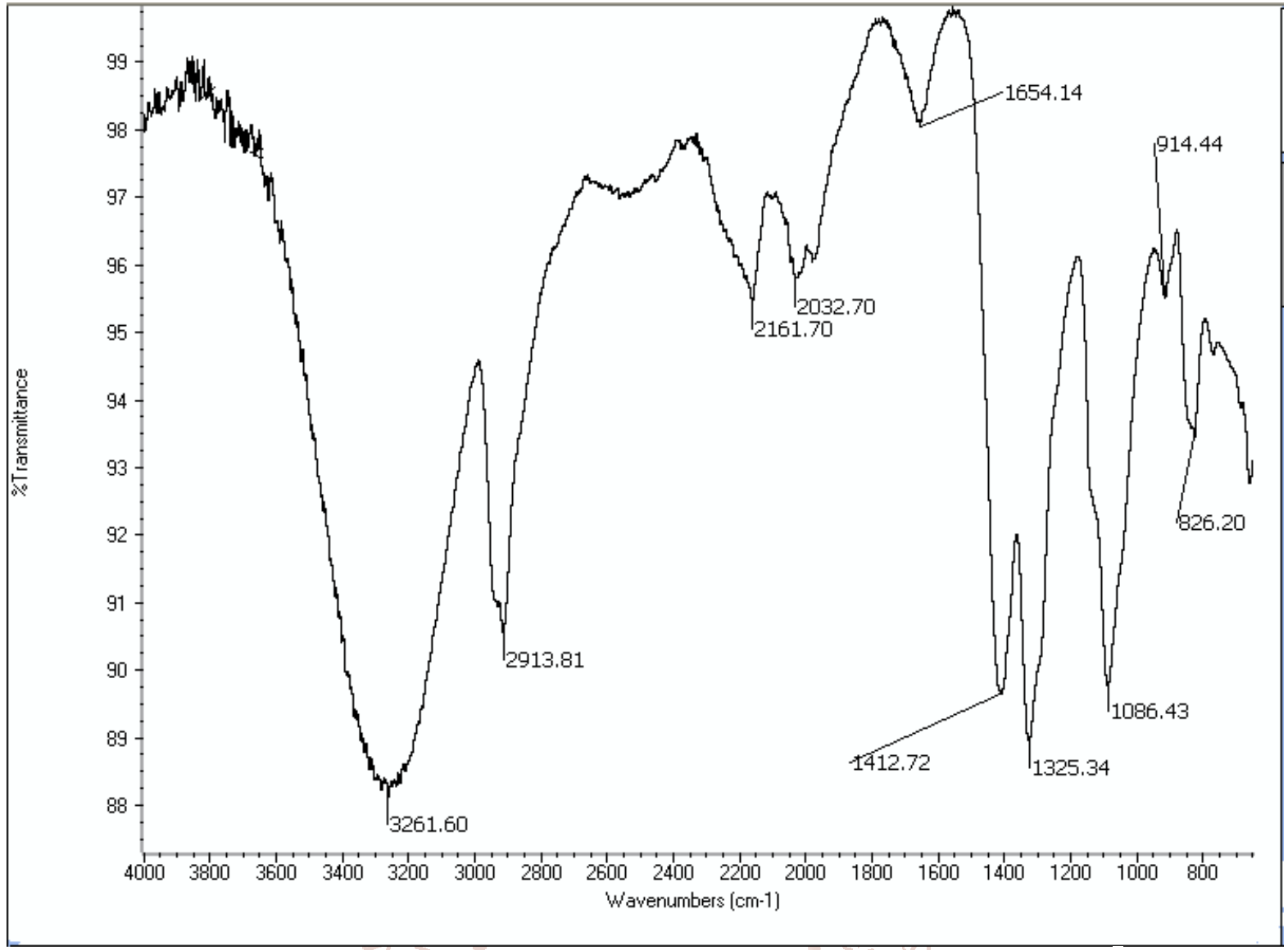

Fig.3. FT-IR spectrum analysis for the composite fibers of the $\mathrm{Mg}_{2} \mathrm{~B}_{2} \mathrm{O}_{5} / \mathrm{PVA}$ at $1200{ }^{\circ} \mathrm{C}$

\subsection{X-ray Diffraction (XRD):}

Fig. 4 and 5 shows the XRD pattern of as-prepared $\mathrm{Mg}_{2} \mathrm{~B}_{2} \mathrm{O}_{5}$ nanofibers in calcination temperature at 800 and $1200^{\circ} \mathrm{C}$. All of the diffraction peaks can be indexed as a triclinic $\mathrm{Mg}_{2} \mathrm{~B}_{2} \mathrm{O}_{5}$ structure (JCPDS Card No: 83-0625). The characteristic peaks at 31.78, 35.38 and 45.2 in the spectrum can be readily corresponded to [200], [-220], [0-21], [-32 0], [-131] and [141] crystal planes of $\mathrm{Mg}_{2} \mathrm{~B}_{2} \mathrm{O}_{5}$. The image diffraction peaks recommend that the patterns could be well crystallized. $\mathrm{Mg}_{2} \mathrm{~B}_{2} \mathrm{O}_{5}$ nanofibers with high purity were obtained.

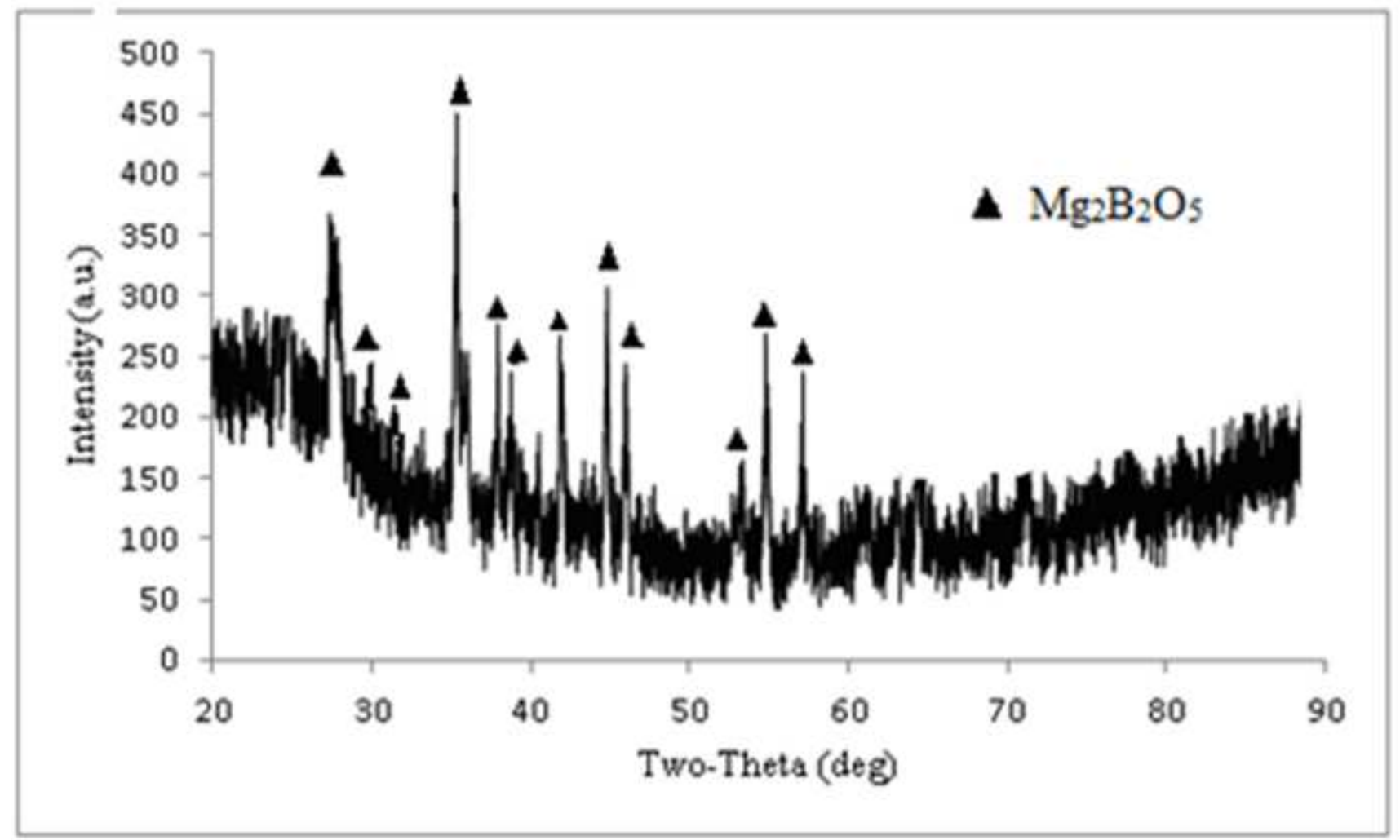

Fig.4. XRD pattern of $\mathrm{Mg}_{2} \mathrm{~B}_{2} \mathrm{O}_{5}$ nanofibers at $800{ }^{\circ} \mathrm{C}$. 


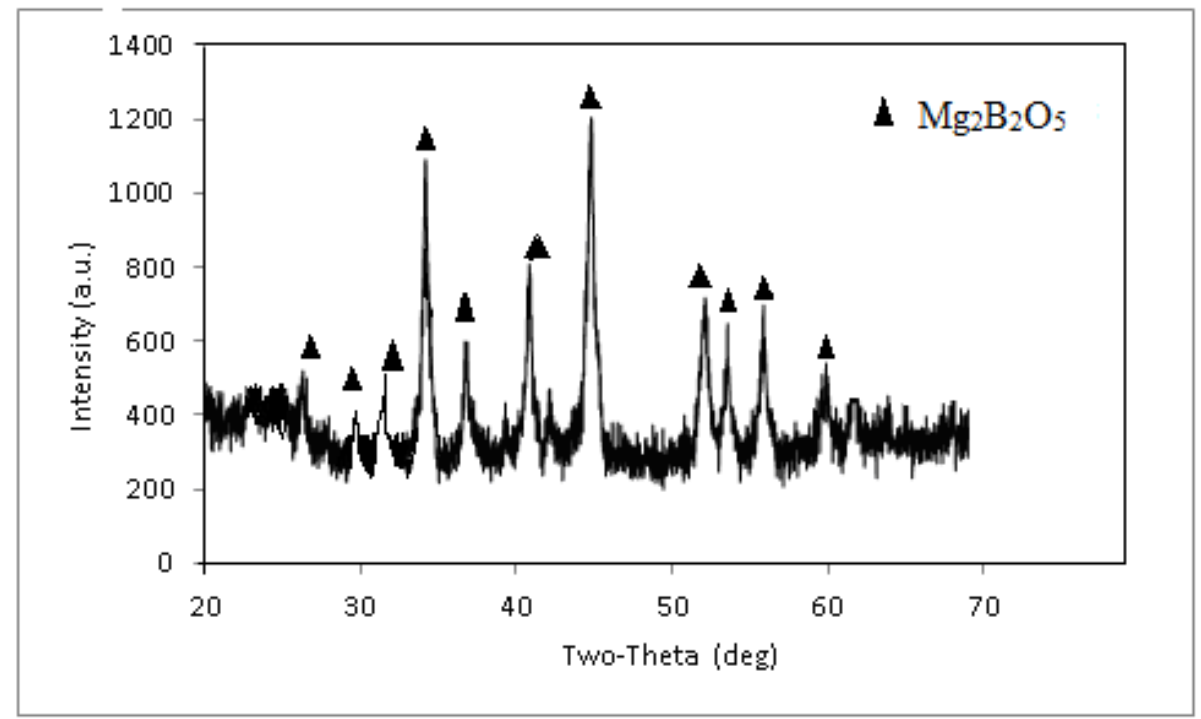

Fig.5. XRD pattern of $\mathrm{Mg}_{2} \mathrm{~B}_{2} \mathrm{O}_{5}$ nanofibers at $1200^{\circ} \mathrm{C}$.

\subsection{Scanning electron microscopy (SEM):}

Fig. 6- $\underline{8}$ show before calcined, $800{ }^{\circ} \mathrm{C}$ and $1200{ }^{\circ} \mathrm{C}$ calcined, respectively. It was used Image $\mathrm{J}$ programming for particle diameters. SEM appearances of the magnesium borate before calcined are shown an irregular structure which beaded in Fig. 6. High-magnification SEM image shown in Fig. 7-8 presents that the product displays one-dimensional nanostructures which was consisted of a regular quantity of nanofibers. The plain nanofibers formed a web-like appearance and having a uniform diameter with an average of about $150 \mathrm{~nm}$.

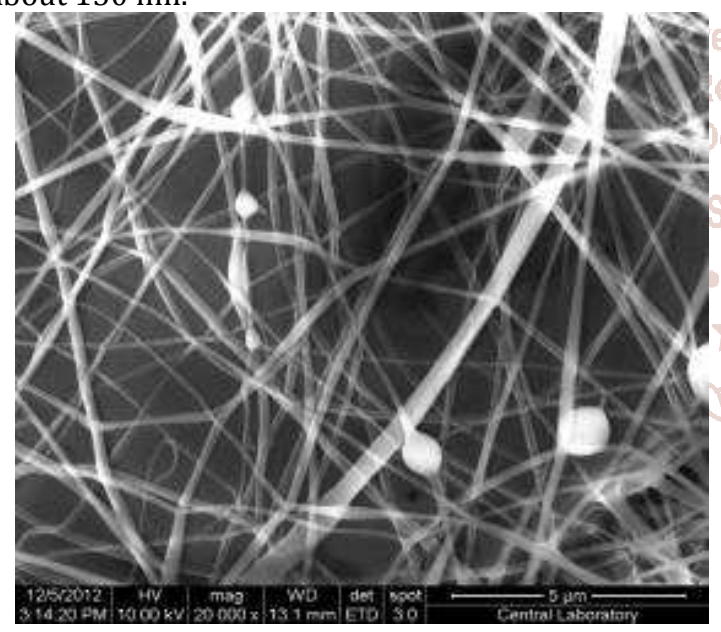

Fig.6. SEM image of synthesized nanofibers before calcined

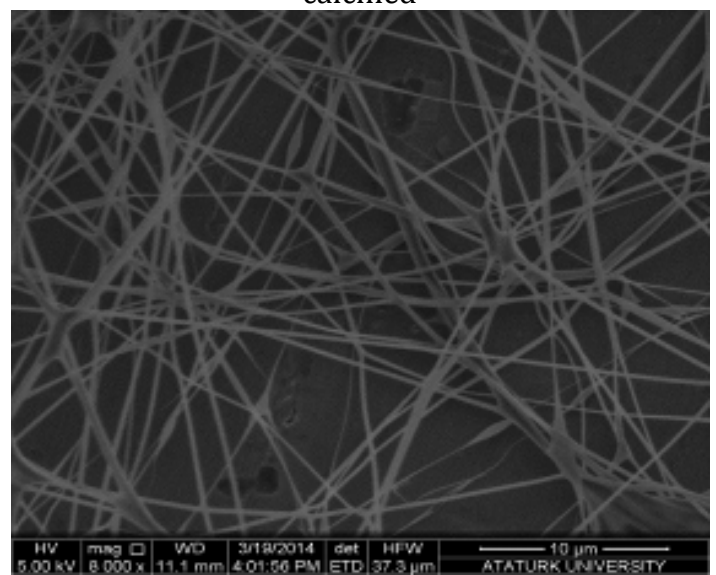

Fig.7. $800^{\circ} \mathrm{C}$ SEM image of synthesized nanofibers

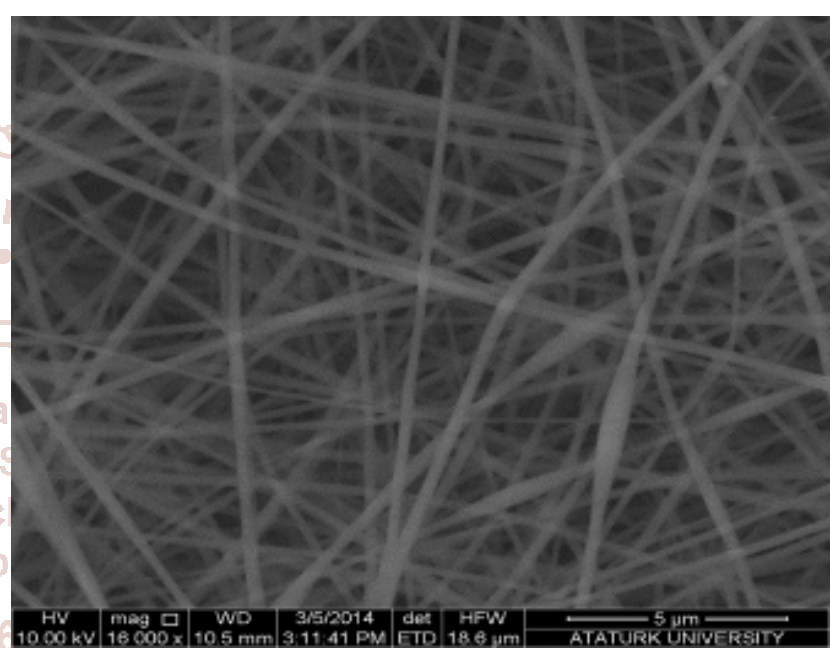

Fig.8. $1200^{\circ} \mathrm{C}$ SEM image of synthesized nanofibers

\section{CONCLUSIONS}

$\mathrm{Mg}_{2} \mathrm{~B}_{2} \mathrm{O}_{5}$ /PVA fibers were prepared by the sol-gel process and fabricated by electrospinning. This method is simple and effective to produce nanofibers of inorganic oxide composite. On the basis of XRD results of products at different stages, indicate that the formation of $\mathrm{Mg}_{2} \mathrm{~B}_{2} \mathrm{O}_{5}$ nanofibers. The SEM investigation unclosed that the diameters of these nanofibers became more uniform after calcination. The TGA thermograms indicated that the thermal stability of the nanofibers was improved, which demonstrated the formation of secondary bonds. In addition, the NMR thermograms at $800-1650 \mathrm{~cm}^{-1}$ appears new peak groups, which may be associated to the formation of inorganic phase crystalline at these temperatures. The best yield and the uniform morphology of $\mathrm{Mg}_{2} \mathrm{~B}_{2} \mathrm{O}_{5}$ nanofibers can be obtained from high temperature calcination at $800{ }^{\circ} \mathrm{C}$ and $1200{ }^{\circ} \mathrm{C}$ with diameters down to $100-200 \mathrm{~nm}$.

\section{References}

[1] L. Kumari, W. Z. Li, S. Kulkarni, K. H. Wu, W. Chen, C. L. Wang, C. H. Vannoy, R. M. Leblanc, Effect of Surfactants on the Structure and Morphology of Magnesium Borate Hydroxide Nanowhiskers Synthesized by Hydrothermal Route. Nanoscale Research Letters, 5 (2010) 149-157. 
[2] W. C. Zhu, G. D. Li, Q. Zhang, L. Xiang, S. L. Zhu, Hydrothermal mass production of $\mathrm{MgBO}_{2}(\mathrm{OH})$ nanowhiskers and subsequent thermal conversion to $\mathrm{Mg}_{2} \mathrm{~B}_{2} \mathrm{O}_{5}$ nanorods for biaxially oriented polypropylene resins reinforcement. Powder Technology, 203 (2010) 265-271.

[3] S. Li, D. P. Xu, H. Z. Shen, J. Zhou, Y. Fan, Synthesis and Raman properties of magnesium borate micro/nanorods. Materials Research Bulletin, 47 (2012) 3650-3653.

[4] X. Y. Tao, X. D. Li, Catalyst-free synthesis, structural, and mechanical characterization of twinned $\mathrm{Mg}_{2} \mathrm{~B}_{2} \mathrm{O}_{5}$ nanowires. Nano Letters, 8 (2008) 505-510.

[5] U. Dosler, M. M. Krzmanc, D. Suvorov, The synthesis and microwave dielectric properties of $\mathrm{Mg}_{3} \mathrm{~B}_{2} \mathrm{O}_{6}$ and $\mathrm{Mg}_{2} \mathrm{~B}_{2} \mathrm{O}_{5}$ ceramics. Journal of the European Ceramic Society, 30 (2010) 413-418.

[6] Z. S. Hu, R. Lai, F. Lou, L. G. Wang, Z. L. Chen, G. X. Chen, J. X. Dong, Preparation and tribological properties of nanometer magnesium borate as lubricating oil additive. Wear, 252 (2002) 370-374.

[7] M. Koruk, I. Girgin, Synthesis of magnesium borates using sodium borate and magnesium sulfate. Journal of Non-Crystalline Solids, 355 (2009) 965-969.

[8] Y. Zeng, H. B. Yang, W. Y. Fu, L Qiao, L. X. Chang, J. J. Chen, H. Y. Zhu, M. H. Li, GT Zou, Synthesis of magnesium borate $\left(\mathrm{Mg}_{2} \mathrm{~B}_{2} \mathrm{O}_{5}\right)$ nanowires, growth mechanism and their lubricating properties. Materials Research Bulletin, 43 (2008) 2239-2247.

[9] Z. H. Liang, S. Li, P. Z. Lu, C. M. Fan, Electrochemical synthesis of magnesium borate whisker. Journal of Applied Electrochemistry, 41 (2011) 961-963.

[10] A. F. Qasrawi, T. S. Kayed, A.Mergen, M. Gürü, Synthesis and characterization of $\mathrm{Mg}_{2} \mathrm{~B}_{2} \mathrm{O}_{5}$. Materials Research Bulletin, 40 (2005) 583-589.

[11] S. H. Chen, P. P. Jin, G. Schumacher, N. Wanderka, Microstructure and interface characterization of a cast $\mathrm{Mg}_{2} \mathrm{~B}_{2} \mathrm{O}_{5}$ whisker reinforced AZ91D magnesium alloy composite. Composites Science and Technology 70 (2010) 123-129.

[12] E. M. Elssfah, A. Elsanousi, J. Zhang, H. S. Song, C. Tang: Synthesis of magnesium borate nanorods. Materials Letters 61 (2007) 4358-4361.

[13] W. C. Zhu, L. Xiang, Q. Zhang, X. Y. Zhang, LH u, S.L. Zhu, Morphology preservation and crystallinity improvement in the thermal conversion of the hydrothermal synthesized $\mathrm{MgBO}_{2}(\mathrm{OH})$ nanowhiskers to $\mathrm{Mg}_{2} \mathrm{~B}_{2} \mathrm{O}_{5}$ nanowhiskers. Journal of Crystal Growth 310 (2008) 4262-4267.

[14] Y. Z. Jia, S. Y. Gao, S. P. Xia, J. Li, FT-IR spectroscopy of supersaturated aqueous solutions of magnesium borate. Spectrochimica Acta Part a-Molecular and Biomolecular Spectroscopy, 56 (2000) 1291-1297.

[15] S. Li, X. Fang, J. Leng, H. Z. Shen, Y. Fan, D. P. Xu: A new route for the synthesis of $\mathrm{Mg}_{2} \mathrm{~B}_{2} \mathrm{O}_{5}$ nanorods by mechano-chemical and sintering process. Materials Letters, 64 (2010) 151-153.

[16] A.S. Kipcak, M. Yildirim, S. Aydin Yuksel, E. Moroydor Derun, S. Piskin, Thesynthesis and physical properties of magnesium borate mineral of admontite synthesized from sodium borates, Adv. Mater. Sci. Eng. 2014 (2014) $1-9$.

[17] D.H. Reneker, A.L. Yarin, H. Fong, S. Koombhongse, Bending instability of elec-trically charged liquid jets of polymer solutions in electrospinning, J. Appl. Phys., 87 (2000) 4531.

[18] X. Shi, W. Zhou, D. Ma, Q. Ma, D. Bridges, Y. Ma, et al., Electrospinning of nanofibers and their applications for energy devices, J. Nanomater. 4 (2015) 1-20.

[19] F. Sevim, E. Sevimli, Structure Investigations of $\mathrm{NiO} / \mathrm{Al}_{2} \mathrm{O}_{3} / \mathrm{B}_{2} \mathrm{O}_{3} / \mathrm{SiO}_{2}$ Composite Based on PVA Using Sol-Gel Processing and the Electrospinning Technique. Asian Journal of Chemistry, 26 (2014) 2293-2295.

[20] A. L. Yarin, S. Koombhongse, D. H. Reneker, Taylor cone and jetting from liquid droplets in electrospinning of nanofibers, J. Appl. Phys. 90 (2001) 4836.

[21] E. Storti, M. Roso, M. Modesti, C. G. Aneziris, P. Colombo, Preparation and morphology of magnesium borate fibers via electrospinning. Journal of the European Ceramic Society, 36 (2016) 2593-2599.

[22] J. Zhang, Z. Li, B. Zhang, Formation and structure of single crystalline magnesiumborate $\left(\mathrm{Mg}_{3} \mathrm{~B}_{2} \mathrm{O}_{6}\right)$ nanobelts, Mater. Chem. Phys., 98 (2006) 195-197.

[23] F. Sevim, E. Sevimli, F. Demir, T. Çalban, The Effect of Parameters on Productions of $\mathrm{NiO} / \mathrm{Al}_{2} \mathrm{O}_{3} / \mathrm{B}_{2} \mathrm{O}_{3} / \mathrm{SiO}_{2}$ Composite Nanofibers by Using Sol-Gel Processing and Electrospinning. World Academy of Science, Engineering and Technology, International Journal of Environmental, Chemical, Ecological, Geological and Geophysical Engineering, 9 (2015) 381-384. 